\title{
Features of somatotype and body weight component composition in patients with acne: boys and girls of Podillya region of Ukraine
}

\author{
IgOr Gunas $^{1 *}$, Olexandr Majewski ${ }^{2}$, Irina MaKarChuK ${ }^{2}$
}

${ }^{1}$ International Academy of Integrative Anthropology, Pyrogov 56, Vinnytsia, 21018, Ukraine

${ }^{2}$ Vinnitsa National Medical University named after M.I. Pirogov, Pyrogov 56, Vinnytsia, 21018, Ukraine

\begin{tabular}{|c|c|}
\hline ARTICLE INFO & ABSTRACT \\
\hline $\begin{array}{l}\text { Received } 07 \text { March } 2016 \\
\text { Accepted } 01 \text { April } 2016\end{array}$ & $\begin{array}{l}\text { The article describes the differences in peculiarities of somatotype and body weight } \\
\text { component composition in patients with acne, the study population being boys and girls }\end{array}$ \\
\hline $\begin{array}{l}\text { Keywords: } \\
\text { somatotype components, } \\
\text { body weight composition, } \\
\text { boys, } \\
\text { girls, } \\
\text { acne. }\end{array}$ & $\begin{array}{l}\text { of the Podillya region of Ukraine. In the study subjects, regardless of sex, body muscle } \\
\text { mass, bone mass and the mesomorphic somatotype component of those with acne were } \\
\text { significantly greater, while fat body mass indicators and the endomorphic somatotype } \\
\text { component was smaller - in comparison to that of non-afflicted subjects of similar } \\
\text { gender. Regarding the ectomorphic component of somatotype, between the surveyed } \\
\text { groups of those with and without acne, whether male or female, no significant differences } \\
\text { were revealed. For all indicators, whether the somatotype components or the component } \\
\text { composition of body weight, between groups of boys or girls with different degrees of } \\
\text { severity of acne, again no significant differences were established. }\end{array}$ \\
\hline
\end{tabular}

\section{INTRODUCTION}

Modern medicine is a unity of science on which is formed clinical medical thinking. An important objective of this activity is to preserve and strengthen the health of man, as well as to prevent, treat and rehabilitate those with pathological conditions. In this regard, there is need for deep knowledge of human biology. This is the field of clinical anthropology [1,2].

Acne is a disease with a polygenic autosomal dominant type of inheritance [3]. In fact, the genetic component provides an explanation of individual differences in predisposition to development of this disease. Moreover, it provides an explanation of the varying degrees of its manifestations and susceptibility to various means of therapy [4].

To date, the accumulation of enough material to generate a thorough study of the pathogenesis of skin diseases has come about only by using a constitutional approach. This allows an identification within one nosology of individual variability of morphological and functional parameters of patients with one or another pathology $[3,5,6]$.

If we consider the evolution of the doctrine of the human physical development, then in all studies, a basic indicator of the physical development of man is considered to

\footnotetext{
* Corresponding author

e-mail: igor.gunas@mail.ru
}

be weight. However, anthropological studies indicate that weight alone does not give an objective picture of the human individual without its fractionation into bone, muscle and fat components [2]. Furthermore, the component structure of the human body is largely dependent on the type of activity undertaken by the human entity, and the habitat to which it is exposed to $[7,8]$.

The aim of this study was to determine the effect of featured somatotype components and body weight component composition in both male and female patients with acne, from the Podillya region of Ukraine.

\section{MATERIALS AND METHODS}

A clinical laboratory and anthropological examination was undertaken of 84 male patients with acne (including 42 with mild severity, 31 - with medium severity, 11 - severe degree) and 116 female patients with acne (including 72 with mild severity, 39 - with an average severity, 9 - severe degree) from the Podillya region of Ukraine. The obtained results were compared with the data of an anthropo-somatotypological survey of 150 apparently healthy males and 160 females of similar age and region of residence obtained from a database held by the M.I. Pirogov Scientific and Research Center of Vinnitsa National Medical University (Ukraine). 
The study utilized the following methods: general clinical - to verify the diagnosis and severity of acne (according to the Acne Dermatology Index - American Academy of Dermatology, 1999-2000); anthropometry - employing the V.V. Bunak approach (a modification of that of P.P. Shaparenko) [9]; somatotype determination - according to the method proposed by J. Carter and B. Heath [10]; component composition assessment of the body mass [11]; statistical analysis of the results - conducted by way of «STATISTICA 6.0» (licensed), using parametric and nonparametric methods.

\section{RESULTS AND DISCUSSION}

The results of the research component inclusive of the composition parameters of body weight and component somatotypes in non-afflicted young males and females, as well as those afflicted with acne, including that broken down by way of the severity of the disease variant, are revealed in Table 1.

Previous studies indicate that muscle and bone mass have significant influence on the human capacity, enhancing or diminishing its physical possibilities and its use of energy resources. Hence, individual differences in the composition of active body weight (muscle and bone components) are the result of the impact of physical activity, diet and genetic factors [2].

At the same time, it has been established that the greater the fat content (endomorphic) component (which is more typical for the hypersthenic), the lower the content of the extracellular matrix. Conversely, the higher the percentage of active body weight (actual normosthenic), the more interstitial spaces exist within the intercellular matrix of the dermis. In these, a sufficiently viscous fluid is found that holds liquid water within the interstices [12]. It is believed that the amount of tissue fluid affects the dynamics of the spread in the skin of microorganisms, toxic substances and cellular elements that participate in relevant immune responses. Ultimately, all this determines the speed of pathological processes, the nature of generalization, and, of course, the severity and characteristics of clinical manifestations of dermatoses [13].

In our work, according to guidelines established by Matejko, the muscle mass of the body in non-afflicted boys or girls was significantly lower than in all groups of patients of similar sex $(p<0,01-0,001)$ (see Table 1). Moreover, the bone mass of the body in non-afflicted boys or girls was significantly lower $(p<0,05-0,01)$ than that in the total group of patients with acne. This figure was also significantly less ( $p<0,05-0,001)$ when non-afflicted girls were compared with girl patients with mild acne, and in both non-afflicted boys or girls when compared with patients of both sexes with an average degree acne severity. In addition, a noted strong trend $(p=0.058)$ to higher value of this indicator was revealed in regard to boy patients with an average severity of acne, when compared with boys with a mild outbreak of acne (see Table 1).

Previous work has recognized that fat mass is most responsive to the changing of metabolic state of the body, whether normal or diseased [2]. This fat, which is part of the protein-lipid complex of an organism's cells, is necessary for the normal functioning of organs and tissues [7]. Therefore, establishing the limits of variation of fat mass among the studied in a normal and in a pathological condition, is extremely promising. In our work, we noted that the body fat mass in non-afflicted boys or girls was significantly higher $(\mathrm{p}<0,05-0,001)$ than that in all groups of the afflicted of similar sex (see Table 1).

What is more, we revealed that the endomorphic somatotype component in non-afflicted boys was significantly higher ( $p<0.001$ in all cases) than that of males, in general, who were afflicted, and particularly when compared with that of boys demonstrating either a mild or average degree of severity of acne outbreak. Furthermore, we detected a strong trend $(p=0.056)$ to higher values with regard to the endomorphic somatotype component of non-afflicted girls when compared to girls enduring a mild acne outbreak (see Table 1).

Table 1. Indicators of somatotype component and composition of body weight in non-afflicted and acne afflicted young men and girls $(\mathrm{M} \pm \sigma)$

\begin{tabular}{|c|c|c|c|c|c|c|c|c|c|c|c|}
\hline Indicator & Sex & $\mathrm{H}$ & $\mathrm{P}$ & $P_{m}$ & $P_{a}$ & $\mathrm{p}$ & $\mathrm{p}_{1}$ & $\mathrm{p}_{2}$ & $\mathrm{p}_{3}$ & $\mathrm{p}_{4}$ & $\mathrm{p}_{5}$ \\
\hline \multirow{2}{*}{$\begin{array}{l}\text { Muscle mass of body } \\
(\mathrm{kg})\end{array}$} & $Y$ & $32,51 \pm 4,54$ & $35,38 \pm 5,42$ & $35,05 \pm 5,82$ & $35,91 \pm 5,68$ & $p<0,001$ & $\mathrm{p}<0,05$ & $p<0,01$ & $>0,05$ & $>0,05$ & $>0,05$ \\
\hline & G & $26,21 \pm 3,83$ & $28,42 \pm 4,55$ & $28,41 \pm 4,69$ & $28,44 \pm 4,58$ & $\mathrm{p}<0,001$ & $p<0,001$ & $p<0,01$ & $>0,05$ & $>0,05$ & $>0,05$ \\
\hline \multirow{2}{*}{$\begin{array}{l}\text { Bone mass of body } \\
(\mathrm{kg})\end{array}$} & Y & $11,09 \pm 1,25$ & $11,48 \pm 1,66$ & $11,27 \pm 1,92$ & $11,67 \pm 1,30$ & $p<0,05$ & $>0,05$ & $p<0,05$ & $>0,05$ & $>0,05$ & $=0,058$ \\
\hline & G & $7,995 \pm 1,010$ & $8,413 \pm 1,111$ & $8,276 \pm 1,188$ & $8,612 \pm 0,971$ & $p<0,01$ & $p<0,05$ & $\mathrm{p}<0,001$ & $>0,05$ & $>0,05$ & $>0,05$ \\
\hline \multirow{2}{*}{$\begin{array}{l}\text { Fatty mass of body } \\
(\mathrm{kg})\end{array}$} & $Y$ & $9,449 \pm 2,491$ & $7,350 \pm 3,000$ & $7,427 \pm 3,138$ & $7,362 \pm 3,342$ & $p<0,001$ & $p<0,001$ & $p<0,001$ & $>0,05$ & $>0,05$ & $>0,05$ \\
\hline & G & $9,075 \pm 2,994$ & $7,908 \pm 2,944$ & $7,801 \pm 3,152$ & $7,974 \pm 2,688$ & $p<0,01$ & $p<0,001$ & $p<0,01$ & $>0,05$ & $>0,05$ & $>0,05$ \\
\hline \multirow{2}{*}{$\begin{array}{l}\text { Endomorphic component } \\
\text { (points) }\end{array}$} & $Y$ & $2,725 \pm 0,805$ & $2,246 \pm 0,998$ & $2,282 \pm 0,944$ & $2,256 \pm 1,220$ & $p<0,001$ & $p<0,001$ & $p<0,001$ & $>0,05$ & $>0,05$ & $>0,05$ \\
\hline & G & $2,811 \pm 1,123$ & $2,601 \pm 1,031$ & $2,586 \pm 1,099$ & $2,602 \pm 0,960$ & $>0,05$ & $=0,056$ & $>0,05$ & $>0,05$ & $>0,05$ & $>0,05$ \\
\hline \multirow{2}{*}{$\begin{array}{l}\text { Mesomorphic component } \\
\text { (points) }\end{array}$} & Y & $4,233 \pm 0,954$ & $4,686 \pm 1,405$ & $4,657 \pm 1,552$ & $4,801 \pm 1,299$ & $p<0,01$ & $>0,05$ & $p<0,05$ & $>0,05$ & $>0,05$ & $>0,05$ \\
\hline & G & $3,391 \pm 1,166$ & $3,925 \pm 1,296$ & $3,864 \pm 1,406$ & $3,971 \pm 1,100$ & $p<0,001$ & $\mathrm{p}<0,05$ & $>0,05$ & $>0,05$ & $>0,05$ & $>0,05$ \\
\hline \multirow{2}{*}{$\begin{array}{l}\text { Ectomorphic component } \\
\text { (points) }\end{array}$} & Y & $3,152 \pm 1,017$ & $2,965 \pm 1,246$ & $2,848 \pm 1,307$ & $2,970 \pm 1,252$ & $>0,05$ & $>0,05$ & $>0,05$ & $>0,05$ & $>0,05$ & $>0,05$ \\
\hline & G & $3,057 \pm 1,241$ & $2,882 \pm 1,334$ & $2,895 \pm 1,309$ & $2,907 \pm 1,449$ & $>0,05$ & $>0,05$ & $>0,05$ & $>0,05$ & $>0,05$ & $>0,05$ \\
\hline
\end{tabular}

Notes: $\mathrm{Y}$ - young men; G - girls; $\mathrm{H}$ - non-afflicted; $\mathrm{P}$ - patients in general; $\mathrm{P}_{\mathrm{m}}$ - patients with mild acne severity; $\mathrm{P}_{\mathrm{a}}$ - patients with an average severity of acne; $p$ - significant differences between non-afflicted boys or girls and boys or girls suffering from acne in general; $p_{1}-$ significant differences between non-afflicted boys or girls and patients with mild acne severity; $p_{2}$ - significant differences between non-afflicted boys or girls and patients with an average severity of acne; $\mathrm{p}_{3}$ - significant differences between patients with acne boys or girls in general and patients with mild acne severity; $p_{4}$ - significant differences between patients with acne boys or girls in general and patients with an average severity of acne; $p_{5}$ - significant differences between patients with mild acne severity boys or with acne boys or girls in general and patients with
girls and patients with an average severity of acne. 
Beyond this, the mesomorphic somatotype component in non-afflicted boys or girls was significantly lower ( $p<0,05$ $0,001)$ than in the total group of the afflicted of both sexes, as well as in girl patients with mild acne, and boy patients with moderate severity of acne (see Table 1).

A leading factor in acne pathogenesis comes about during embryogenesis, and concerns the connective tissue involved in the formation of hair follicles and sebaceous glands [4]. The fine structure of the skin is genetically controlled, and the mechanism of determination has application to both the macromolecular and supramolecular level of their organization. According to A.A. Gaidash and others [12], in the non-afflicted, the dominating ectomorphic somatotype component intermediate has a more hydrophobic surface of collagen fibrils and a less viscous liquid interstitium, when compared with the mesomorph. It is noted that an excess of fibrillar mass in the extracellular matrix coincides with elevated remodeling of collagen fibers. This is inevitably accompanied by an accumulation of «waste» materials which certainly reduces the rate of utilization of detritus and increases the risk of the clogging of nano channels. This situation creates favorable conditions for the development of acne defeats of a skin, even in clinically healthy individuals $[14,15]$. This explains the fact that no significant differences were evidenced for the ectomorphic component of somatotype between the surveyed groups of non-afflicted and afflicted boys and girls (see Table 1).

N.A. Kornetov [1] had noted that: «regarding pathological processes and disease states, the genotype reaction norm substantially defines the boundaries of clinical variability, polymorphism and pathomorphism manifestations of human diseases». Hence, the degree of manifestation of acne is the phenotypic response of the patient to the impact of exogenous and endogenous factors.

Thus, in our study, with regard to groups of boys or girls with different degrees of severity of acne, we revealed virtually no significant differences or trends for differences in all indicators of somatotype components and component composition of body weight.

Consequently, somatotype components, as well as component composition of body weight may serve as markers of morphogenetic risk of developing acne and its complicated variants. This, we feel, is an important step in developing suitable prognostic criteria for the primary prevention of manifestation of multifactorial diseases.

\section{CONCLUSIONS}

In boys and girls afflicted with acne, when compared with the non-afflicted, body muscle mass, the rate of bone mass body, as well as the mesomorphic somatotype component are significantly greater, while indicators of fat mass body and the endomorphic somatotype component are smaller.

Moreover, with regard to the ectomorphic component of somatotype, between the surveyed groups of afflicted and non-afflicted, no significant differences were seen.

Finally, for all the indicators of somatotype components and component composition of body weight no significant differences were established between the groups of boys or girls with different degrees of severity of acne and those without.

\section{REFERENCES}

1. Kornetov N.A. Clinical anthropology - methodological basis for a holistic approach in medicine. Proceedings of the international conference "Current issues and achievements of modern anthropologists", Novosibirsk, 2006.

2. Nikitiuk B.A., Moroz V.M., Nikitiuk D.B. Theory and practice of integrative anthropology. Essays. Kiev-Vinnitsa: Zdorov'ya, 301, 1998.

3. Samtsov A.V. Acne and acneforme dermatosis. Monograph M.: OOO "YUTKOM", 288, 2009.

4. Szabó K., Kemény L. Studying the genetic predisposing factors in the pathogenesis of acne vulgaris. Human Immunology, 72, 9, 2011.

5. Kobileva N.G., Prohorenkov V.I. Ethnic peculiarities of the state of the skin in health and acne. Siberian Journal of Dermatology and Venereology, 2, 10, 2009.

6. Koynosov A.P. Clinical and constitutional studies in dermatology. Tutorial. Tyumen, Shadrinsk, 135, 2010.

7. Al-Gindan Y.Y. et al. Derivation and validation of simple anthropometric equations to predict adipose tissue mass and total fat mass with MRI as the reference method. British Journal of Nutrition. $114,11,2015$

8. Richard Pierson N. Jr. Quality of the Body Cell Mass: Body Composition in the Third Millennium Serono Symposia USA. Springer Science \& Business Media, 345, 2012.

9. Shaparenko P.P. Anthropometry. Vinnitsa, 71, 2000.

10. Carter J.E.L. The Heath-Carter anthropometric somatotype. Instruction Manual. Surrey, Canada: TeP and Rosscraft, 154, 2002.

11. Nikolic S. et al. Analysis of body mass components in national club football players in republic of Macedonia. Medicine Archives. 68, $3,2014$.

12. Gaydash A.A. et al. The structure of the extracellular matrix of the skin of various human somatotypes according to the data of atomic force microscopy. Siberian Medical Journal. 5, 2011.

13. Hans Fecht J., Kai Brühne. Carbon-based Nanomaterials and Hybrids: Synthesis, Properties, and Commercial Applications. CRC Press, 220, 2014.

14. Thierry Ondarçuhu, Jean-Pierre Aimé. Nanoscale Liquid Interfaces: Wetting, Patterning and Force Microscopy at the Molecular Scale. CRC Press, 780, 2013.

15. Ke-Li Han, Guang-Jiu Zhao. Hydrogen Bonding and Transfer in the Excited State. John Wiley \& Sons, 970, 2011. 
